\title{
Synthesis of Gold Nanoparticles by using Batch Method and Study its Antibacterial Activity
}

\author{
Mahmood Mohammed Ali ${ }^{1}$
}

Firas Fadhel Ali $^{2} \quad$ Ahmed Mishaal Mohammed ${ }^{1 *}$

Received 21/9/2019, Accepted 7/1/2020, Published 23/6/2020

\begin{abstract}
:
The research involves preparing gold nanoparticles (AuNPs) and studying the factors that influence the shape, sizes and distribution ratio of the prepared particles according to Turkevich method. These factors include (reaction temperature, initial heating, concentration of gold ions, concentration and quantity of added citrate, reaction time and order of reactant addition). Gold nanoparticles prepared were characterized by the following measurements: UV-Visible spectroscopy, X-ray diffraction and scanning electron microscopy. The average size of gold nanoparticles was formed in the range $(20-35) \mathrm{nm}$. The amount of added citrate was changed and studied. In addition, the concentration of added gold ions was changed and the calibration curve was calculated used to estimate Au ions in different samples. The effectiveness of gold nanoparticles prepared according to Turkevich method was studied as antibacterial agents against E. coli bacteria. The minimum inhibition concentration of gold nanoparticles that inhibit bacterial growth was calculated using the broth dilution method, which is based on several dilutions to determine the inhibition concentration.
\end{abstract}

Key words: AuNPs, Antibacterial activity, Characterization, Inverse method, Turkevich method.

\section{Introduction:}

Nanotechnology has revolutionized science in recent years and its applications are being used in the conversion of solar energy (1), catalysis (2), in addition to biomedicine (3) and biosensor (4). One of the most important methods used in the manufacture of AuNPs is Turkevich method which generally involves reducing the $\left(\mathrm{Au}^{3+}\right)$ to $\left(\mathrm{Au}^{0}\right)$ by adding reducing agents such as amino acids, citrates (5) or ascorbic acid. Other methods used $\mathrm{NaBH}_{4}$ as a reducing agent and alkanethiols as a stabilizer (6). The physical methods to synthesize AuNPs include using laser ablation (7) or ultrasonic induction (8) while the biological methods include using microbial enzymes (9) and plants (10).There is a mechanism for growth based on nucleation and another which depends on seed composition. Regarding the growth mechanism based on the seed, this mechanism consists of four steps (11). These steps include partial reduction of gold ions to form seeds at $1.5 \mathrm{~nm}$ diameters, and the remaining gold ions are collected by a double electron layer (DEL) on the surface of the seed particle.

\footnotetext{
1 Department of Chemistry, College of Science, University of Anbar, Ramadi, Iraq.

${ }^{2}$ Department of Chemistry, College of Education for Women, University of Anbar, Ramadi, Iraq.

*Corresponding author:
}

Then followed by slow growth by reducing. Finally, a rapid reduction of gold ions loaded on seeds to form nanoparticles.

Nanotechnology-specific scientific studies confirm the effectiveness of nanoparticles as antimicrobial agents. Furthermore, gold nanoparticle affects Staphylococcus aureus cells and leads to biological changes such as cellular membrane decay, damage DNA, and negatively affecting cellular functions such as protein synthesis and metabolism (12), finally inhibits cell growth. Nanoparticle is a powerful and highly effective agent for a range of positive and negative bacteria (E. coli, Enterobacter cloacae, P. aeruginosa) which cause urinary tract diseases and resistance to many antibiotics (13).

The aim of the research is to prepare gold nanoparticles by chemical methods and study the factors affecting the shapes and sizes of the nanoparticles formed and study the antibacterial activity of AuNPs against Escherichia coli bacteria and to determine the minimum inhibitory concentration (MIC) of $\mathrm{Au}^{3+}$ that used to inhibit bacterial growth using broth method. 


\section{Materials and Methods:}

\section{Chemical solutions}

The solution of trisodium citrate

One gm of the trisodium citrate was dissolved in $(100 \mathrm{~mL})$ of distilled water to produce percentage of concentration of citrate 1\% (34 $\mathrm{mmol} / \mathrm{L}$ ).

\section{The solution of $\mathrm{HAuCl}_{4} \cdot 3 \mathrm{H}_{2} \mathrm{O}$}

One gm of chloroauric acid was dissolved in (100 $\mathrm{mL})$ of distilled water to prepare $(25 \mathrm{mmol} / \mathrm{L})$ as a stock solution. The required concentrations could be prepared by carrying out successive dilution processes.

AuNPs preparation method (Standard preparation

Solution A $\left(\mathrm{HAuCl}_{4} \cdot 3 \mathrm{H}_{2} \mathrm{O}\right)$ was prepared after dilution with distilled water to different concentrations. After dilution by using distilled water, $(50 \mathrm{~mL})$ of solution was taken and heated at $95{ }^{\circ} \mathrm{C}$ by a magnetic hot plate with continuous stirring for 10 minutes. $(5 \mathrm{~mL})$ of solution $\mathrm{B}$ was added to (trisodium citrate $\mathrm{Na}_{3} \mathrm{C}_{6} \mathrm{H}_{5} \mathrm{O}_{7}$ ). The solution was heated and stirred continuously for 20 minutes. Then, the colour of the solution changed to red. The solution then was cooled at room temperature and maintained in the refrigerator at 4 ${ }^{\circ} \mathrm{C}$.

\section{Antibacterial activity of AuNPs}

The method of Broth dilution was used in order to study the antibacterial activity of AuNPs (14). This method involves using several tubes and doing a series of dilution to find the minimum inhibitory concentration (MIC). The process can be described with the following points:

1- Adding (2 mL) of Lauryl Tryptose Broth (L.T.B) to a series of tubes. (L.T.B is a medium used to detect coliform bacteria in sanitary materials and wastewater).

2- Adding ( $2 \mathrm{~mL})$ of AuNPs into the first tube and mix with the material L.T.B.

3- Transfering ( $2 \mathrm{~mL})$ of the first tube and adding to the second tube and mixing with the material L.T.B, the process continues with the third tube until reaching the last tube.

4- Adding ( $2 \mathrm{~mL}$ ) of material Lauryl Tryptose Broth (L.T.B) to two tubes considered as a negative control and positive control.

5- All tubes except the negative control are fertilized with $(0.2 \mathrm{~mL})$ of bacterial growth (concentration $1.5 \times 10^{8} \mathrm{CFU}$ ). Shake the tubes and store them in an incubator at $37^{\circ} \mathrm{C}$ for 24 hour.

\section{Results and Discussion:}

Parameters influence on particle growth, shapes and the final size of AuNPs prepared.

\section{- $\mathrm{Au}^{3+}$ concentration}

Many solutions of gold nanoparticles were prepared by using Turkevich methods and changing the concentration of gold ions. The lowest concentration of $\mathrm{Au}^{3+}$ was $(10 \mathrm{mg} / \mathrm{L})$. Otherwise, the concentration is insufficient to prepare the gold nanoparticle (gold particles does not enough to form the seeds).

\section{Spectral characterization}

\section{-UV-Visible Spectroscopy}

Through the UV-Visible spectrum, much information can be obtained to characterize the prepared samples and study the effect of changing the concentration of the reactants as shown in Fig.1.

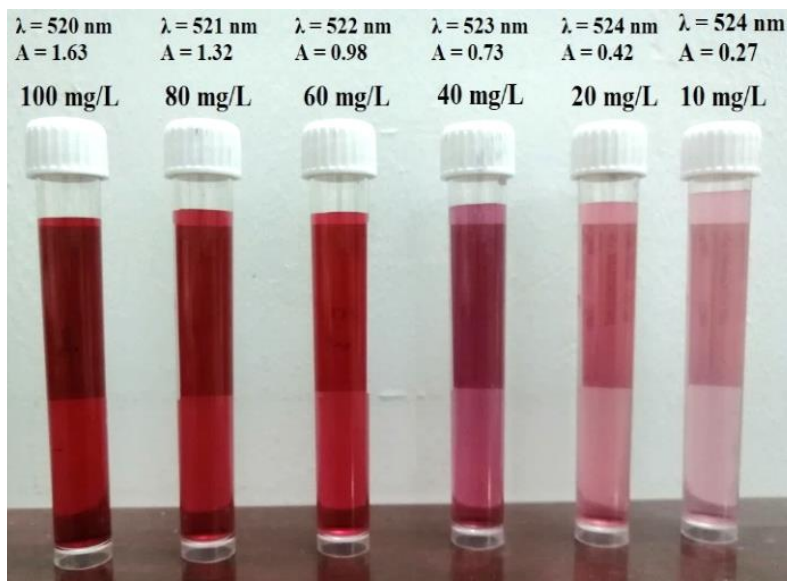

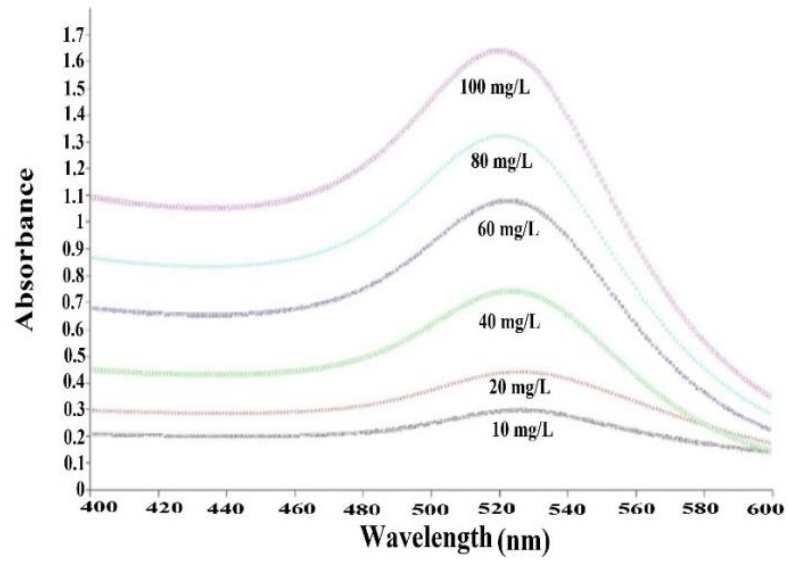

Figure 1. Absorbance for different concentrations of $\mathrm{Au}^{3+}$

From Fig.1, it is noted that increasing the concentration of the gold ions leads to changes in color, absorbance, and $\max$ wavelengths (wavelength is decreasing and suffer a blue shifting
(15)). In addition, according to the seed growth mechanism (16) (The high concentration of $\mathrm{Au}^{3+}$ will provide a greater probability to reduction more amounts of gold ions which will provides more 
monomers of $\mathrm{Au}^{0}$. These monomers form the seeds; these seeds determine the final size of the particles).
Producing more seeds means a greater distribution of residual gold ions on these seeds which lead to small final size as shown in Fig.2

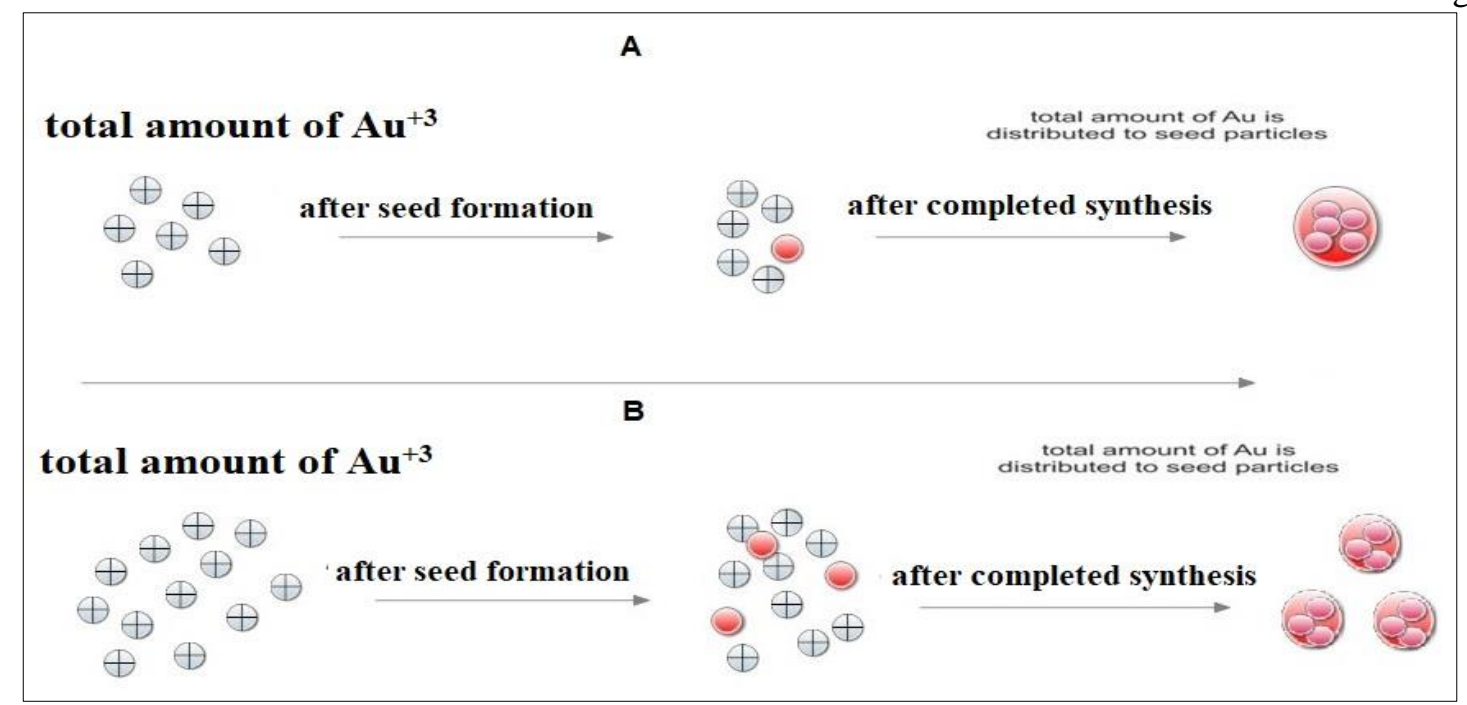

Figure 2. The effect $\mathrm{Au}^{3+}$ concentration According to theory seed growth mechanism A) Concentration of $\mathrm{Au}^{3+}=20(\mathrm{mg} / \mathrm{L}), \quad$ B) concentration of $\mathrm{Au}^{3+}=100(\mathrm{mg} / \mathrm{L})$

Kimling $\mathrm{J}$, et al (17) explained that the increased concentration of $\mathrm{HAuCl}_{4}$ will reduce the particle sizes of the gold nanoparticles formed. Results showed that when increasing the concentration of $\mathrm{HAuCl}_{4}$ from $0.125 \mathrm{M}$ to $0.5 \mathrm{M}$, the sizes of the formed nanoparticles decrease from $14 \mathrm{~nm}$ to $5 \mathrm{~nm}$. The reason for the decrease in the particle sizes of gold nanoparticles is because the value of Chloroauric acid will determine the ratio of $\left[\mathrm{AuCl}_{4}\right]^{-}$, and increasing the amount $\left[\mathrm{AuCl}_{4}\right]$ means to produce more seeds, which leads to forming smaller particles.

Polte J, et al (18) proved by using the method of analysis that depend of X-ray absorption near-edge spectroscopy (XANES) that changing the concentration of $\mathrm{HAuCl}_{4}$ from $0.25 \mathrm{mmol}$ to 0.375 mmol (stabilizing other conditions, temperature 75 ${ }^{\circ} \mathrm{C}$, concentration of citrate $2.5 \mathrm{mmol}$ ) will leads to a decrease in the particles sizes in addition to significantly accelerating the formation of nanoparticles as it leads to increase the reaction rate.

\section{X-ray diffraction (XRD)}

$\mathrm{X}$-Ray diffraction patterns of the sample are shown in Fig.3 compared with ICDD card no. 00004-0784 as the standard reference of the AuNPs. The diffraction peaks indexed to (111), (200), (220), and (311) planes were observed, confirming the AuNPs face centered cubic (fcc) showed that peaks at $2 \theta=38.1^{\circ}, 44.3^{\circ}, 64.5^{\circ}$, and $77.7^{\circ}$ respectively which observed in all samples as shown in Fig.3.

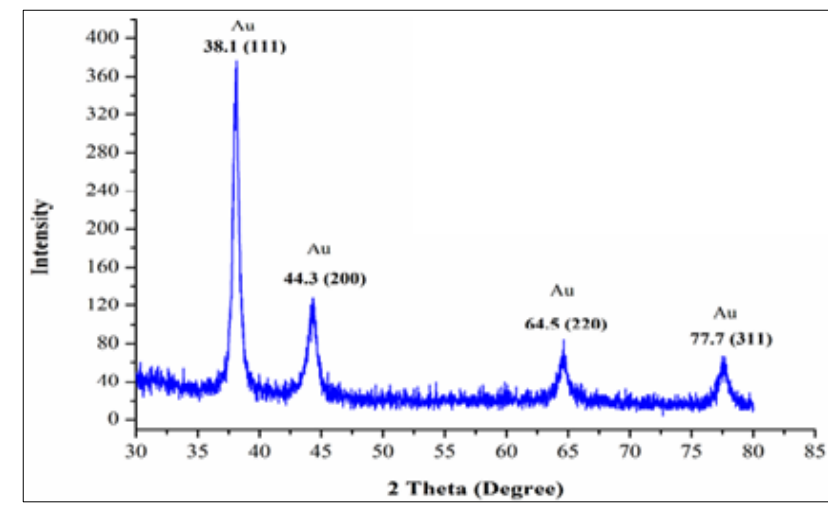

Figure 3. X-ray diffraction pattern of AuNPs compared to standard $\mathrm{Au}\left(\mathrm{Au}^{3+}\right.$ concentration $100 \mathrm{mg} / \mathrm{L})$.

\section{Scanning electron microscope (SEM)}

SEM micrographs show in Fig. 4, in particular, the morphological characteristic and size of the measured grains AuNPs and the structure of the particles. The morphology shape of the AuNP shows uniform nanostructures with an average size in the range of SEM at different magnifications 


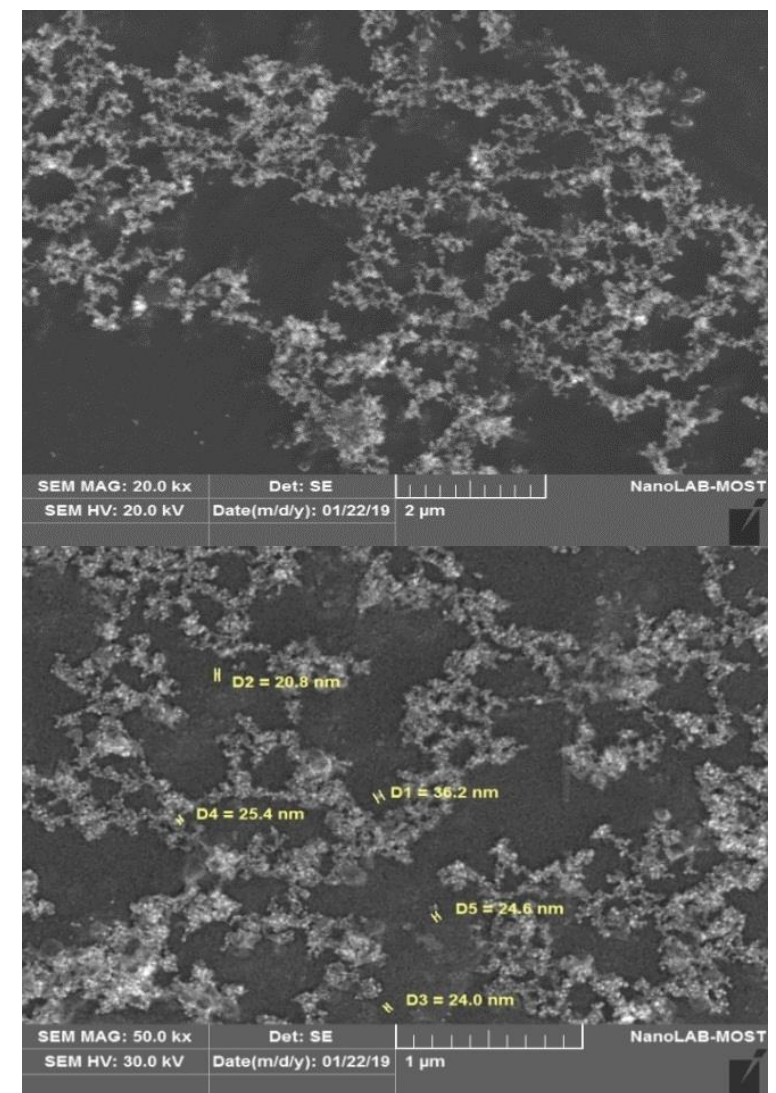

Figure 4. SEM micrograph of AuNPs in different magnification $\left(\mathrm{Au}^{3+}\right.$ concentration $\left.100 \mathrm{mg} / \mathrm{L}\right)$

\section{The effect of citrate}

By changing the amount of citrate and kept the other conditions constant, the following results were obtained as shown in Fig.5.
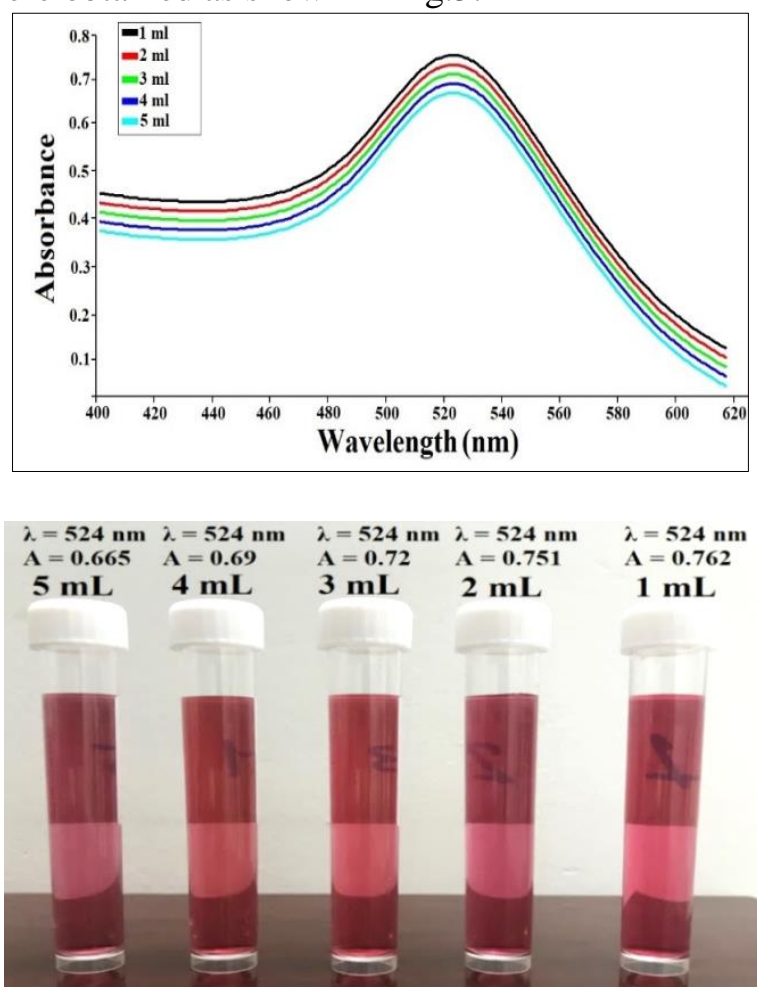

Figure 5. Absorbance for different amounts of citrate
From Fig.5, it is noted that the absorption value is very converged. Increasing the volume of citrate shows its effect on the gold nanoparticle over time. Increasing the amount of citrate reduces the stability of the nanoparticles, then increases the size of the nanoparticle by the aggregation process (19). This is noticed when using $5 \mathrm{~mL}$ of citrate. The colour of the solution changes to purple over time as a result of the aggregation process. It was found that the effect of using different volumes of citrate is negligible 1, 2, 3, 4 solutions.

Islam $\mathrm{Z} \mathrm{A}$, et al (19) studied the effect of increasing the amount of citrate from 0.5 to $3 \mathrm{~mL}$ on the gold nanoparticles formed. Results showed that the absorbance peaks were significantly close, even though the values of SPR are similar (520.8 and 520.93) $\mathrm{nm}$ respectively. Additionally, the effect of increasing the amount of citrate on the resulting particle sizes is small (65.1 and 70.44) $\mathrm{nm}$ respectively and the only effect is that it affects the mono dispersity. Add more citrate means to get less mono dispersity.

Kumar S, et al (20) found that the concentration of the citrate has no effect on the final size of the particles as long as its buffer ability guarantees a neutral $\mathrm{pH}$ value when it reacts with $\mathrm{HAuCl}_{4}$. The results proved that changing the concentration of citrate from $2.5 \mathrm{mmol}$ to 3.75 mmol will change the final size of the particles very slightly (13.8 and 14.2) nm respectively.

\section{Reaction time}

Over time, the radius of particles increases as explained in the theory of seed growth. As shown in Table 1 and Fig.6, the absorption value will increase over time until reaching the end of the reaction. It can be observed in Table 1 the required time for converting $\mathrm{Au}^{3+}$ to the nanoscale at different concentrations (100 and 20) $\mathrm{mg} / \mathrm{L}$.

When using different concentrations of gold ions, the reaction time will vary. At high concentrations of gold ions, the time needed to reach the nanoscale is less. The change in reaction time can be understood through seed formation theory. Increasing the concentration leads to an increase in the number of seeds formed and thus increases the whole surface area of the seed surface that attracted or attached by Au ions. Therefore, the kinetics of steps 3, 4 (from seed growth mechanism) are increased. 
Table 1. Observation for change the absorbance over time

\begin{tabular}{cccc}
\hline $\begin{array}{r}\text { Time } \\
(\mathrm{min})\end{array}$ & $\begin{array}{c}\text { Concentration } \\
\text { of } \\
\mathrm{Au}^{3+}(\mathrm{mg} / \mathrm{L})\end{array}$ & Absorbance & $\begin{array}{c}\text { Wavelength } \\
(\mathrm{nm})\end{array}$ \\
\hline \multirow{2}{*}{1} & 20 & $/$ & $/$ \\
& 100 & $/$ & $/$ \\
4 & 20 & $/$ & $/$ \\
& 100 & 0.252 & 535 \\
6 & 20 & $/$ & $/$ \\
& 100 & 0.454 & 531 \\
10 & 20 & 0.12 & 528 \\
& 100 & 0.826 & 527 \\
15 & 20 & 0.32 & 525 \\
& 100 & 1.522 & 523 \\
\hline
\end{tabular}

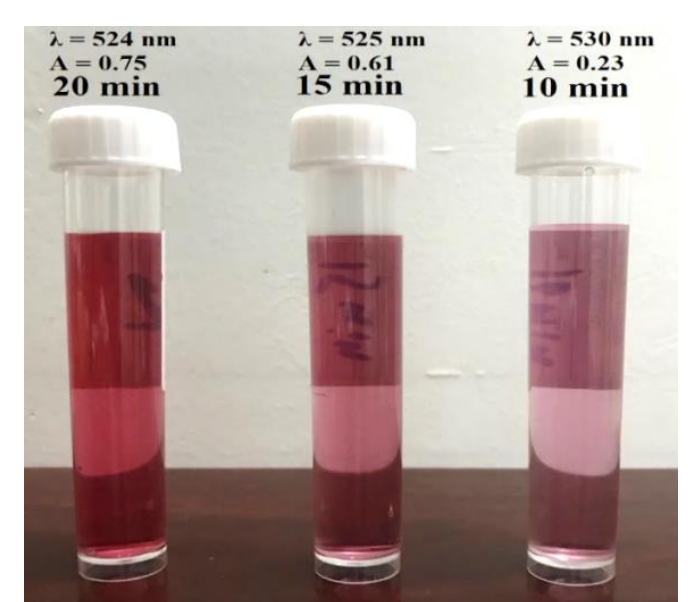

Figure 6. Effect of reaction time on synthesis AuNPs (40 mg/L) of $\mathrm{Au}^{3+}$

Hendel $\mathrm{T}$, et al (21) studied the effect of reaction time on gold nanoparticles formed and proved that although absorbance changed over time, the final size of the particles is determined in the seed formation step (the second step of seed growth mechanism). The results assumed that if the standard method to produce gold nanoparticles requires $17 \mathrm{~min}$, the seed formation step will take place during the first minutes which consumes 5\% of the gold ions concentration. Therefore, the determination of the particle size will be within a short time. The only effect that changes over time is poly dispersity, which decreases over time.

\section{Effect of temperature}

The composition of the nanoparticles and the sizes formed are related to the reaction temperature. Using high temperatures usually produces smaller particle sizes. On the other side, at room temperature, the particles have large diameters and poly dispersity greater than $25 \%$. These diameters decrease with increasing temperature until reaching the ideal temperature (22). It should be noted that increasing the temperature would reduce the required time for converting $\mathrm{Au}^{3+}$ to the nanoscale as shown in Fig.7.

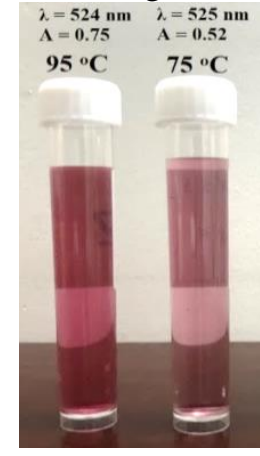

A

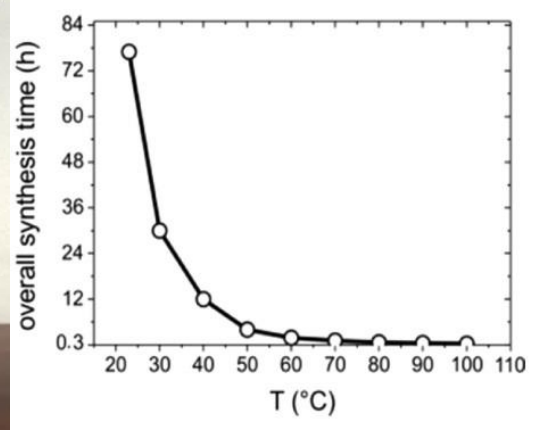

B
Figure 7. A- AuNPs solution at different temperatures (conc. of $\mathrm{Au}^{3+}=40 \mathrm{mg} / \mathrm{L}$ ), B- Total synthesis time vs. temperature.

Polte J, et al (18) studied the effect of changing the reaction temperature on the gold nanoparticles formed. The results showed that raising the reaction temperature from $75{ }^{\circ} \mathrm{C}$ to $85{ }^{\circ} \mathrm{C}$ leads to a rising in the absorbance peaks. A higher temperature will lead to the faster formation of the nanoparticles. Likewise, the increase in temperature leads to an increase the reaction rate, and that is mean to get smaller particles (assuming that there is no interference between the particles at high temperatures)

\section{Initial heating}

Without preheating of $\mathrm{HAuCl}_{4} \cdot 3 \mathrm{H}_{2} \mathrm{O}$, the nucleation process is not fast enough and we get a very broad size distribution. Therefore, the key to this method is that nucleation occurs fast practically exhausting the supply of gold ions as shown in Fig.8.

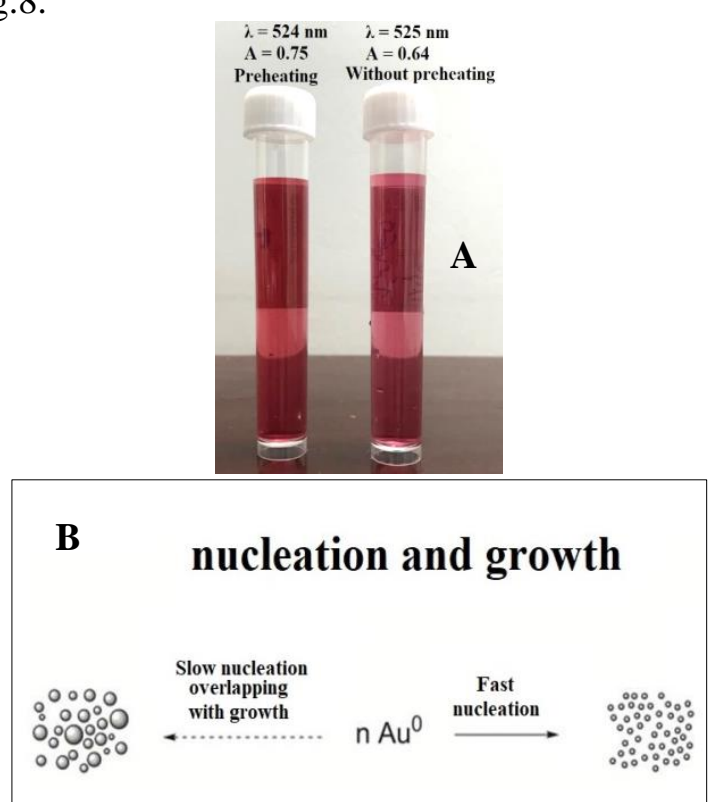

Figure 8. A- Effect of preheating on Absorbance (conc. of $\mathrm{Au}^{3+}=40 \mathrm{mg} / \mathrm{L}$ ), B- Effect of preheating on the size distribution. 


\section{Inverse method of preparing AuNPs}

The inverse method could apply by adding a solution of chloroauric acid (high concentration) into a large volume of preheated citrate solution. It was found that using this method the final particle sizes and reaction time decreases. Changing the order of addition of reactants affects the final size of the particles as shown in Fig. 9.

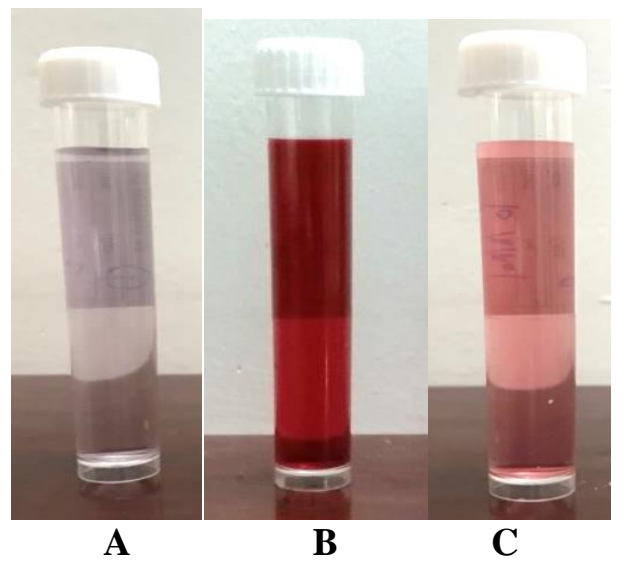

Figure 9. Methods of synthesis AuNPs

A- Inverse method (conc. of $\mathrm{Au}^{3+}=100 \mathrm{mg} / \mathrm{L}$ ), conc. of citrate $=38 \mathrm{mM}, \lambda=529, \mathrm{Abs}=0.151$ )

B- Standard method (conc. of $\mathrm{Au}^{3+}=100 \mathrm{mg} / \mathrm{L}$ ), conc. of citrate $=38 \mathrm{mM}, \lambda=520, \mathrm{Abs}=1.59$ )

$\mathrm{C}$ - Inverse method (conc. chloroauric acid $=\mathbf{1 0}$ $\mathrm{mM}\left(\mathrm{Au}^{3+} 2000 \mathrm{mg} / \mathrm{L}\right)$, conc. of citrate $=0.5$ $\mathrm{mM}, \lambda=519, \mathrm{Abs}=0.49$ )

The concentration of gold ions is usually about $(1000-10000) \mathrm{mg} / \mathrm{L}$, and the concentration of the citrate range from (0.5-1) mmol.

Sivaraman S, et al (23) explained that adopting the inverse method for producing gold nanoparticles leads to the formation of particles with sizes ranging from (5-10) $\mathrm{nm}$ (unlike the standard method that produces particles greater than $10 \mathrm{~nm}$ ). The results demonstrated also that the order of addition process has a role in producing monodisperse nanoparticles. Using inverse methods will make the timescale of synthesis shorter and synthesis of nanoparticle will be completed in less than $3 \mathrm{~min}$ compared with the standard method that lasts $10 \mathrm{~min}$.

\section{Application of Batch method in $\mathrm{Au}^{3+}$ estimation}

Using the increasing concentrations of gold ions, the calibration curve of AuNPs solutions is shown in Fig. 10, the linearity of the results were $(10-100)$ $\mathrm{mg} / \mathrm{L}, \mathrm{R}^{2} 0.9988$, correlation coefficient 0.9993 and the detection limit $5 \mathrm{mg} / \mathrm{L}$.

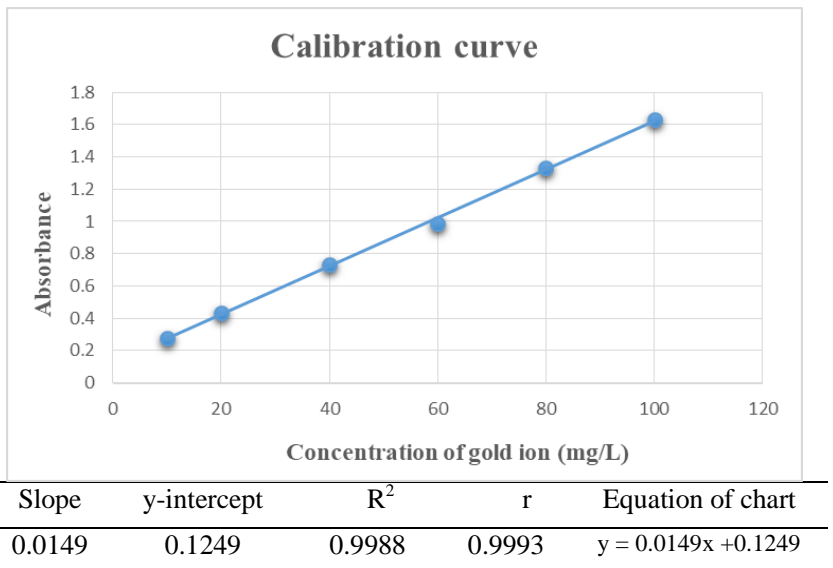

Figure 10. Calibration curve of Batch method Using a calibration curve, it can be estimated $\mathrm{Au}^{3+}$ as shown in the Table 2

Table 2. Estimate $\mathrm{Au}^{3+}$ in various samples by Batch method AAS (Atomic Absorption Spectroscopy), Bat (Batch method)

\begin{tabular}{ccccc} 
Samples & $\begin{array}{c}\text { Concentration } \\
\text { of } \\
\mathrm{Au}^{3+}(\mathrm{AAS}) \\
(\mathrm{mg} / \mathrm{L})\end{array}$ & $\begin{array}{c}\text { Concentration } \\
\text { of } \mathrm{Au}^{3+}(\mathrm{Bat}) \\
(\mathrm{mg} / \mathrm{L})\end{array}$ & $\begin{array}{c}\text { Rec } \\
\%\end{array}$ & $\begin{array}{c}\text { Relative } \\
\text { Error } \%\end{array}$ \\
\hline Aqueous & $\mathbf{3 1 . 1 0}$ & $\mathbf{2 9 . 9}$ & $\mathbf{9 6 . 2}$ & $\mathbf{3 . 8}$ \\
Solutions & $\mathbf{5 2 . 0 5}$ & $\mathbf{4 9 . 7}$ & $\mathbf{9 5 . 5}$ & $\mathbf{4 . 5}$ \\
Gold & $\mathbf{1 1 . 2 0}$ & $\mathbf{9 . 6 7}$ & $\mathbf{8 6 . 3}$ & $\mathbf{1 3 . 6}$ \\
Jewellery & $\mathbf{1 7 . 0 2}$ & $\mathbf{1 4 . 2}$ & $\mathbf{8 3 . 4}$ & $\mathbf{1 6 . 5}$ \\
\hline
\end{tabular}

\section{Antibacterial activity of AuNPs}

In order to study the antibacterial activity of gold nanoparticles, the efficacy of gold nanoparticles was tested against Escherichia coli bacteria. The method used is the Broth dilution method. The broth dilution method expresses results in $(\mathrm{mg} / \mathrm{L})$ or $(\mu \mathrm{g} / \mathrm{mL})$ to determine the MIC, which is considered the lowest concentration to prevent bacterial growth (24). The concentration of $\mathrm{Au}^{3+}$ used in the synthesis of AuNPs was $100 \mathrm{mg} / \mathrm{L}$.

After the preparation and incubation of tubes at 37 ${ }^{\circ} \mathrm{C}$ for 24 hours, the absorbance of the prepared tubes is measured at $(630 \mathrm{~nm})$ and compared with the positive and negative tubes absorption as showed in Table. 3 and Fig .11.

Table 3. Absorption of samples, positive and negative control

\begin{tabular}{cccc}
\hline $\begin{array}{c}\text { Concentration of } \\
\mathrm{Au}^{3+}(\mathrm{mg} / \mathrm{L})\end{array}$ & Absorbance & $\begin{array}{c}\text { Positive } \\
\text { control }\end{array}$ & $\begin{array}{c}\text { Negative } \\
\text { control }\end{array}$ \\
\hline 50 & 0.082 & 0.83 & 0.075 \\
25 & 0.49 & & \\
12.5 & 0.73 & & \\
6.25 & 0.77 & & \\
3.12 & 0.85 & & \\
\hline
\end{tabular}




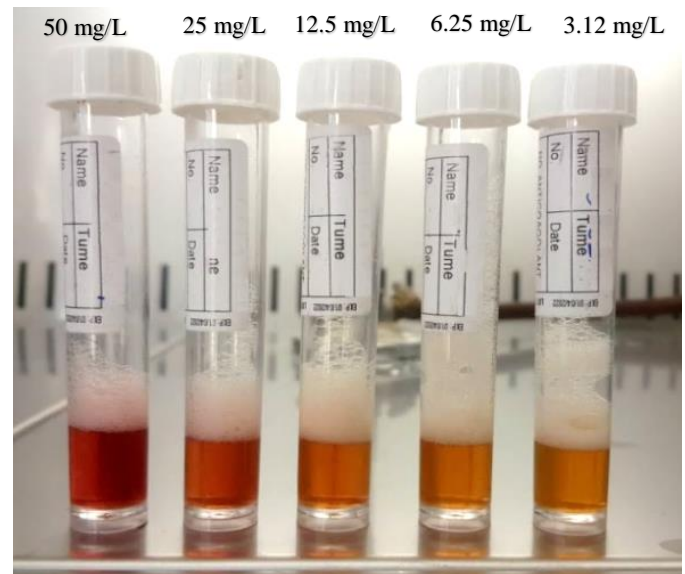

A

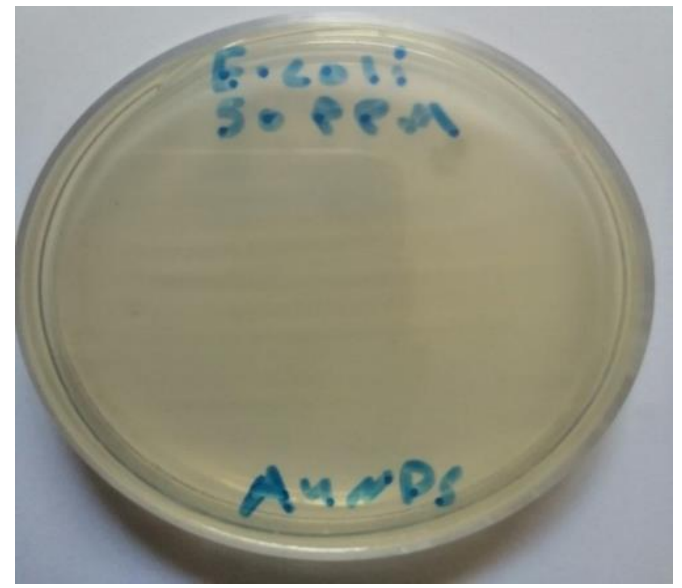

B

Figure 11. The samples prepared to study MIC

It can be seen that the bacteria effect depends on the concentration of the nanoparticles. It shows us that the concentration of $50 \mathrm{mg} / \mathrm{L}$ is the minimum concentration used to inhibit bacterial growth. To ensure the effectiveness of this concentration, we performed a second culture on a nutrient agar plate and incubated this plate at $37{ }^{\circ} \mathrm{C}$ for 24 hour as showed in Fig.11 B. No bacterial growth on the plate proves the antibacterial activity of concentration $50 \mathrm{mg} / \mathrm{L}$. Rai A, et al (25) studied the preparation of AuNPs and cover it with cefaclor (a second-generation antibiotic). The rusltes showed that AuNPs prepared from this method have activity against gram-negative for E. coli. MICs of gold nanoparticles were $100 \mathrm{mg} \mathrm{mL}^{-1}$ for (E. coli).

Odai $\mathrm{N}$, et al (26) studied the effect of AuNPs as an antibacterial against species bacterial such as E.coli. Au nanoparticles were prepared by pulsed laser ablation in liquid (PLAL). The results showed that the AuNPs were less active against gram-positive than the gram-negative. This status could be attributed to the variation in the composition of bacterial cell membranes. Inhibition zone (mm) of AuNPs was (14 for E.Coli).

\section{Conclusions:}

This paper includes the preparation of gold nanoparticle in the standard method and the inverse method. By using the standard method, gold nanoparticles' solutions are prepared with average sizes ranging from (25-40) $\mathrm{nm}$. Changing the parameters that influence the Turkevich method (concentration of gold ions, the temperature, the amount of citrate, the initial heating, the reaction time and change order of reactant addition) show up differences in colors, absorbances, and wavelengths of the prepared AuNPs solutions. These factors according to the theory of seed growth mechanism mean changes in the sizes and poly dispersity of the prepared particles. By changing the concentrations of gold ions, it is possible to draw a calibration curve used to determine the concentrations of gold ions in aqueous solutions and Gold Jewellery after converting them into gold nanoparticles. The results show good recovery and a small relative error. The biological effectiveness of the nanoparticles is studied and the minimum inhibition concentration is calculated using the Broth dilution method, where AuNPs are used to inhibit the bacterial growth of Escherichia coli.

\section{Authors' declaration:}

- Conflicts of Interest: None.

- We hereby confirm that all the Figures and Tables in the manuscript are mine ours. Besides, the Figures and images, which are not mine ours, have been given the permission for republication attached with the manuscript.

- Ethical Clearance: The project was approved by the local ethical committee in University of ALAnbar.

\section{References}

1. Mahian O, Kianifar A, Kalogirou S, Pop I, Wongwises S. A review of the applications of nanofluids in solar energy. Int J Heat Mass Transf. 2013; 57(2): 582-594.

2. Ciriminna R, Falletta E, Della Pina C, Teles J H, Pagliaro M. Industrial applications of gold catalysis. Angew Chem. 2016; 55(46): 14210-14217.

3. Valenzuela S M, Shimoni O .Gold Nanoparticles with Organic Linkers for Applications in Biomedicine. Nanomed-Nanotechnol. 2017; (pp. 69-82). CRC Press.

4. Khalil I, Julkapli N M, Yehye W A, Basirun W J, Bhargava S K. Graphene-gold nanoparticles hybridsynthesis, functionalization, and application in a electrochemical and surface-enhanced raman scattering biosensor. J Mater Sci. 2016; 9(6): 406411.

5. Al-Johani H, Abou-Hamad E, Jedidi A, Widdifield C M, Viger-Gravel J, Sangaru S S, et al. The structure and binding mode of citrate in the 
stabilization of gold nanoparticles. Nat Chem. 2017; 9(9): 890-899.

6. Shah M, Badwaik V, Kherde Y, Waghwani H K, Modi T, Aguilar Z P, et al. Gold nanoparticles: Various methods of synthesis and antibacterial applications. Front Mol Biosci. 2014; 19 (8): 13201344.

7. Nayef U M, Khudhair I M. Synthesis of gold nanoparticles by laser ablation on porous silicon for sensing $\mathrm{CO}_{2}$ gas. IJP. 2018.16 (36): 1-10.

8. Yusof N S, Ashokkumar M. Sono chemical synthesis of gold nanoparticles by using high intensity focused ultrasound. Chem phys chem. 2015; 16 (4):775-781.

9. Ajdari Z, Rahman H, Shameli K, Abdullah R, Abd Ghani M, Yeap S, et al. Novel gold nanoparticles reduced by sargassum glaucescens: Preparation, characterization and anticancer activity. Molecules. 2016 ; 21 (3): 123-131.

10. Shabeeb D A, Mohammed A T, Haider A J. Preparation eco-friend and characteristic of gold nanoparticles by orchid and gum arabic as a reducing agent. DJPS. 2017; 13 (2-part 1): 278-291.

11. Polte J. Fundamental growth principles of colloidal metal nanoparticles-a new perspective, Cryst Eng Comm. 2015; 17 (36): 6809-6830.

12. Ambwani S, Kandpal D, Arora S, Ambwani T K. Cytotoxic effects of gold nanoparticles exposure employing in vitro animal cell culture system as part of nanobiosafety. In AIP Conf Proc. 2016; 1724 (1): 020091-020096.

13. Li X, Robinson S M, Gupta A, Saha K, Jiang Z, Moyano D F, et al. Functional gold nanoparticles as potent antimicrobial agents against multi-drugresistant bacteria, J Am Chem. Soc. 2014; 8(10): 10682-10686.

14. Roshmi T, Soumya K R, Jyothis M, Radhakrishnan E K. Effect of biofabricated gold nanoparticle-based antibiotic conjugates on minimum inhibitory concentration of bacterial isolates of clinical origin. Gold Bull. 2015; 48(1-2): 63-71.

15. Haider, A J, Shabeeb D A, Mohammed A T. Synthesis and stabilization of gold nanoparticles by inverse reduction method using sodium citrate and sodium boro hydride as reducing agent. JUAPS. 2016; 10(1): 37-47.

16. Wuithschick M, Birnbaum A, Witte S, Sztucki M, Vainio U, Pinna N, et al. Turkevich in new robes: Key questions answered for the most common gold nanoparticle synthesis. J Am Chem Soc. 2015; 9 (7): 7052-7071 .

17. Kimling J, Maier M, Okenve B, Kotaidis V, Ballot H, Plech A. Turkevich Method for Gold Nanoparticle Synthesis Revisited. J Phys Chem B. 2006; 110: 15700-15707.

18. Polte J, Ahner T T, Delissen F, Sokolov S, Emmerling F, Thünemann Andreas F, et al. Mechanism of gold nanoparticle formation in the classical citrate synthesis method derived from coupled in situ XANES and SAXS evaluation. J Am Chem Soc. 2010; 132(4): 1296-1301.

19. Islam Z A, Mondal S, Islam M. Applications, synthesis and characterization of gold nano particles. Doctoral dissertation. BRAC Univeristy. 2017:41- 45

20. Kumar S, Gandhi K S, Kumar R. Modeling of Formation of Gold Nanoparticles by Citrate Method. Ind Eng Chem Res. 2007; 46: 3128-3136.

21. Hendel T, Wuithschick M, Kettemann F, Birnbaum A, Rademann K, Polte J. In Situ Determination of Colloidal Gold Concentrations with UVVis Spectroscopy: Limitations and Perspectives. Anal Chem. 2014; 86:11115-11124.

22. Li C, Li D, Wan G, Xu J, Hou W. Facile Synthesis of Concentrated Gold Nanoparticles with Low SizeDistribution in Water: Temperature and pH Controls. Nanoscale Res Lett. 2011; 6:440.

23. Sivaraman S K, Kumar S, Santhanam V. Monodisperse sub-10 nm gold nanoparticles by reversing the order of addition in Turkevich methodThe role of chloroauric acid. J Colloid Interface Sci.2011; 361(2): 543-547.

24. Bueno J. Antimicrobial models in nanotechnology: from the selection to application in the control and treatment of infectious diseases. In Nanotechnology in diagnosis, treatment and prophylaxis of infectious diseases .Academic Press. 2015; (pp. 19-38).

25. Rai A, Prabhune A, Perry C C. Antibiotic mediated synthesis of gold nanoparticles with potent antimicrobial activity and their application in antimicrobial coatings. J Mater. Chem. 2010; 20(32): 6789-6798.

26. Salman O N, Dawood M. O, Ahmed D S. Antibacterial Activity of Gold and Silver Nanoparticles against Pathogen Species, E. coli and S. aureus. IJAP. 2017; 13(3), 19-22. 
تخليق جسيمات الذهب النانوية بأستخدام طريقة الدفعة ودراسة فعاليتها البايلوجية

1

فراس فاضل علي 2

محمود محمد علي 1

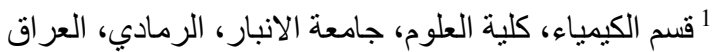

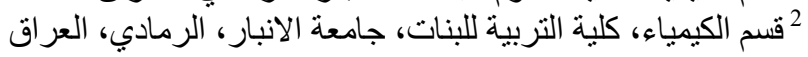

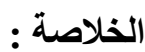

يتضمن هذا البحث تحضير محاليل الذهب النانوية بأستخدام الطريقة القياسية والعكسية. باستخدام الطريقة القياسية ، تم إعداد محاليل

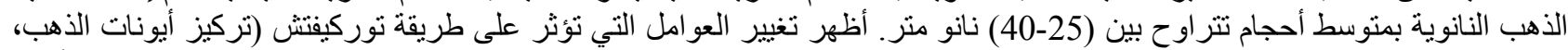

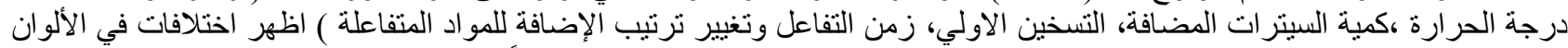

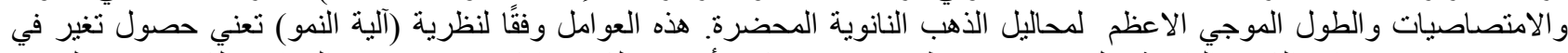

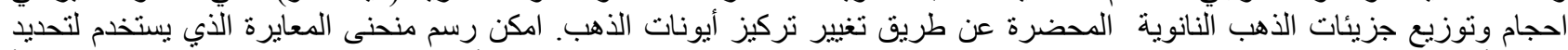

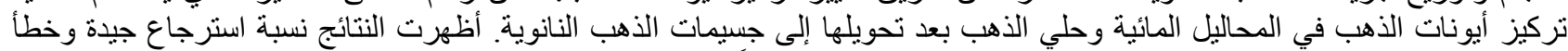

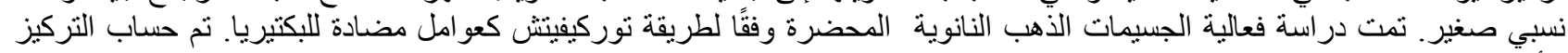

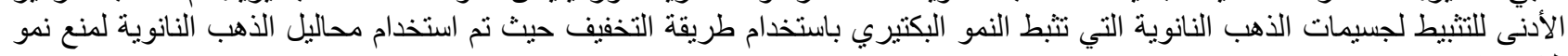

البكتيريا.

الكلمات المفتاحية : AuNPs ، النشاط المضاد للجر اثيم، توصيف، الطريقة العكسية، طريقة توركيفت 